\title{
Malakologie a (nejen) okouzlení internetem Malacology and (not only) fascination by the internet
}

\author{
Luboš R. Kolouch \\ M. Horákové 1095, CZ-50006 Hradec Králové, Česká republika, e-mail: 1rk@seznam.cz
}

Ti, kdož jste již zběhlí v počítačové a internetové vědě, pak prosím o zdrženlivost při dalším čtení. Je určeno počítačovým laikům, nikoliv profíkům. Další řádky mají vyprovokovat čtenáře, aby využívali úžasné vynálezy ku svému prospěchu. Vždyt' žijeme už v jedenadvacátém století :-) Pokud moje zamyšlení pomůže někoho z vás "postrčit" tím správným směrem, pak článek nevyšel zbytečně.

Neškodí připomenout si, že velkou službu za nás konají tzv. vyhledávače. Ty za nás projdou milióny či miliardy různých dat a vyberou pro nás ta nejdůležitější. Nechci žádnému dělat speciální reklamu, ale jistě znáte např. www.seznam.cz, www.altavista.com, www.yahoo.com, www.google.com, Atlas, Kompas, Quick a desítky dalších. Já sám nejvíc využívám google, ale rozhodně ne, coby jediný. Pokud se chcete ve vyhledávačích orientovat, pomůže vám následující webovská stránka http://www.regionycr.cz/vyhledavace.htm .

Vybrali jsme si např. Google. Zadáme klíčové slovo (př́ípadně klíčová slova) česky, či v jiné řeči, které rozumíme (nebo předpokládáme nejvíce nalezených stránek). Zadal jsem (stačí vše malými písmeny) european water mollusca. Vyhledávač našel celkem 2590 odkazů, america water mollusca 3900 odkazů, clausiliidae 760 odkazů, zebrina detrita 98 odkazů, vojen ložek 248 odkazů, sphaeriidae pictures 44 odkazů, quickella 18 odkazů, fossil mollusca 4860 odkazů, alabama terrestrial mollusca 232 odkazů, bibliography rhodos 577 odkazů, ale mollusca bibliography rhodos už pouze jen 4 odkazy, mollusca temelin 1 odkaz, zatímco mollusca temelín už 4 odkazy, musculium 341 odkazů. Uvedl jsem jen několik námětů. Psát jednotlivé adresy, jejichž počet by šel do desetitisíců, to by asi nemělo smysl. Navíc některé adresy vznikají a zase zanikají. Řada nás "šnekařŭ" má některé zajímavé odkazy ve svých "linksech", čili odkazech, u kterých můžete rovněž začít hledat, a ty vás dovedou zase dále. Takže na shledanou na: www.kolouch.com (v současnosti též i kolouch.com)!

\section{Summary}

Author calls attention to great possibilities on the internet when searching for some malacologic information. He gives a few examples of key words in the Google search and number of results found. 